УДК 378.37.01.004

DOI: 10.37026/2520-6427-2019-100-4-65-68

\section{Оксана ШТРІМАЙТІС,}

кандидат фармачевтичних наук, заступник директора з наукової роботи -

завідувач кафедри хіміко-фармачевтичних дисииплін КЗВО «Рівненська медична академія»

Рівненської обласної ради

\section{Оксана ФИЛИПЮК,}

асистент кафедри хіміко-фармачевтичних дисииплін КЗВО «Рівненська медична академія»

Рівненської обласної ради

\section{Тетяна НЕСТЕРУК,}

асистент кафедри хіміко-фармацевтичних дисииплін КЗВО «Рівненська медична академія»

Рівненської обласної ради

\title{
ВИКОРИСТАННЯ ІНТЕГРАЦІЙНИХ ТЕХНОЛОГІЙ ЯК ЗАПОРУКА ПРОДУКТИВНОГО ОСВІТНЬОГО ПРОЦЕСУ
}

У статті описано важливість упровадження 6 освітній проиес міждисииплінарної інтеграиії, різносторонне використання якої сприяє формуванню в студентів професійної компетентності. Доведено, що міждисииплінарні зв'язки допомагають доповнити зміст однієї дисичилліни знаннями з іншої, поєднують їх, забезпечуючи таким чином формування професійно важливих умінь та навичок.

Ключові слова: міждисииплінарна інтеграція, професійна компетентність, продуктивний освітній проиес, інтеграиійні технології.

В статье описана важность внедрения в образовательный процесс междисичиплинарной интеграции, разностороннее использование которой способствует формированию у студентов профессиональной компетентности. Доказано, что междисииплинарные связи помогают дополнить содержание одной дисииплинь знаниями с другой, объединяют их, обеспечивая таким образом формирование профессионально важных умений и навыков.

Ключевые слова: междисичилинарная интеграция, профессиональная компетентность, продуктивный образовательный прочесс, интеграчионные технологии.

The article describes the importance of introducing in the educational process of interdisciplinary integration, the versatile use of which contributes to the formation of professional competence at students. Interdisciplinary connections help to supplement the content of one discipline with knowledge from another, by combining them and providing the formation of professionally important skills.
Integration is an important prerequisite for modern science and for the development of civilization as a whole, because, at the present stage, scientific thinking is increasingly characterized by the ability to consider not separate, isolated objects of the phenomenon of life, but their more or less broad unities. Therefore, integration as a requirement of unification into one whole of certain parts or elements is considered a necessary didactic tool. Reforming modern education is inextricably linked to overcoming isolated teaching of subjects and creating fundamentally new curricula where it is advisable to focus the educational process on a developmental and productive integrative approach.

Productive technologies and methods of educational process are: effective, durable, relevant, successful teaching methods, which are proven both from the standpoint of the results of success and the educational process and from the standpoint of student-oriented approach. A productive educational process is an integral part of the teacher's cooperation with the student, setting student up to the full perception of knowledge in various ways and methods.

Important and relevant, especially for the medical student is now studying a new discipline in the context of the integrational technologies, and will ensure the students to achieve timely high-quality learning process, and will be not only the key to a good current performance, but also a comprehensive approach to the development of the knowledge qualification.

Key words: interdisciplinary integration, professional competence, productive educational process, integration technologies. 
Постановка проблеми. Інтеграція - важлива умова сучасної науки та розвитку цивілізації в цілому, адже на сучасному етапі науковому мисленню дедалі частіше притаманна здатність розглядати не окремі, ізольовані об'єкти явища життя, а їх більш чи менш широкі єдності. Тож інтеграція як вимога об'єднання в одне ціле певних частин чи елементів вважається необхідним дидактичним засобом. Реформування сучасної освіти нерозривно пов'язане із подоланням ізольованого викладання навчальних предметів та створення принципово нових навчальних програм, де освітній процес доцільно орієнтувати на розвивально-продуктивний інтегративний підхід [2, с. 5-6].

Актуальність та важливість використання інтеграційних технологій у освітньому процесі складно переоцінити. Інтеграція - це не просто поєднання, це взаємопроникнення теорії в практику, взаємозближення та утворення взаємозв'язків. Цьому питанню у вищій медичній освіті приділяється значна увага [1, с. 209-211], адже в системі медичної освіти ідея міжпредметного, міждисциплінарного, комплексного підходу є однією із найперспективніших і необхідних [6, с. 86-89]. При цьому важливим є не лише глибоке засвоєння студентами базових знань, а й формування в них широкого світогляду і потреби в постійному оновленні цих знань [5, с. 133-135].

Інтеграція освітнього процесу у вищих медичних закладах освіти передбачає його побудову за принципом логічних узагальнень послідовності програмних дисциплін і «комплексування» навчання [1, с. 209-211].

Інтеграційний підхід у підготовці фахівця медичної сфери дозволяє підняти його на якісно новий рівень клінічного мислення, здатного комплексно вирішувати завдання медичної практики на основі широкого інтегрування даних різноманітних дисциплін [6, c. 86-89].

Аналіз наукових досліджень та публікацій свідчить, що міждисциплінарну інтеграцію в освітньому процесі підготовки студентів-медиків учені розглядають у контексті аналізу таких питань: інтеграція навчального процесу у вищих медичних закладах освіти (М. М. Багрій, Н. М. Воронич-Семченко, О. Г. Попадинець); теоретико-методичні основи інтеграції знань (В. С. Безрукова, М. М. Берулава, О. В. Левчук, М. О. Сова, Т. С. Тітовець, Ю. С. Тюнніков, М. К. Чапаєв та ін.); інтеграція як освітня перспектива (I. Д. Бех); результати впровадження нових технологій навчання при викладанні фармакології (К. А. Посохова, О. М. Олещук, О. О. Шевчук); актуальність упровадження міждисциплінарної інтеграції при вивченні фармакології (С. Ю. Чечотіна).

Змістовний аналіз інтеграційних процесів в освіті й науці представлено також і в дисертаційних дослідженнях (П. Васил'єв, О. Глущенко, А. Козлов, О. Микитюк, О. Нечаєва, 3. Сазонова, Т. Торгашина, В. Чернолєс та ін.).

Слід зазначити, що теорія інтеграції в навчальному процесі не $\epsilon$ новою. У різні роки до ідеї міжпредметних зв'язків, об'єднань педагогічних процесів зверталися як класики науково-педагогічної думки (I. Гербарт, О. Герцен, П. Каптєрєв, Я. Коменський, Дж. Локк, І. Песталоцці, В. Сухомлинський, К. Ушинський та ін.), так і сучасні українські дослідники (Н. Андреєва, В. Асріян, Г. Грибан, Л. Демінська,
О. Сфремова, Н. Захарова, О. Зеленяк, Л. Ковальчук, О. Кругляк, С. Рибак, М. Явоненко та ін.).

Мета статті - охарактеризувати інтеграційні технології та способи освітнього процесу кафедри хіміко-фармацевтичних дисциплін КЗВО «Рівненська медична академія».

Виклад основного матеріалу. Продуктивні технології та способи освітнього процесу - дієві, міцні, актуальні, успішні методи навчання, що доведено як iз позиції результатів успішності, так і самого освітнього процесу з позиції студент-орієнтовного підходу. Продуктивний освітній процес - це невід'ємна частка співпраці педагога зі студентом, налаштування його на повноцінне сприйняття знань різними способами та методами. За результатами освітньої діяльності науково-педагогічним колективом кафедри хімікофармацевтичних дисциплін Рівненської медичної академії (далі - РМА) було проаналізовано низку найбільш дієвих технологій освітнього процесу.

Відповідно до Закону України «Про освіту» (2017) [3] однією з трьох складових системи забезпечення якості освіти є система забезпечення якості в закладах освіти (внутрішня система забезпечення якості освіти). Таким чином, ми звернули увагу на такий важливий момент, як внутрішня система забезпечення якості освіти. Вона включає:

- стратегію (політику) та процедури забезпечення якості освіти;

- систему та механізми забезпечення академічної доброчесності;

- оприлюднені критерії, правила і процедури оцінювання здобувачів освіти.

На нашу думку, спільна реалізація педагогічним колективом означених вище складових призведе до комплексного освоєння необхідних кваліфікаційних знань, сприятиме активному використанню міждисциплінарної інтеграції у процесі навчання.

Інтеграція навчального процесу у вищих медичних закладах освіти передбачає його побудову за принципом логічних узагальнень послідовності програмних дисциплін і «комплексування» навчання. Викладання проводиться таким чином, щоб знання однієї дисципліни були фундаментом для вивчення іншої. При цьому лекції та практичні заняття $є$ надбанням різних фахівців, кожен з яких на високому науково-методичному рівні подає студентам програмний об'єм знань та вмінь. Методичне опрацювання змісту навчальних предметів полягає в систематизації та узагальненні матеріалу, отриманому при вивченні різних дисциплін [1, с. 209-211].

Міждисциплінарна інтеграція допомагає розвинути здатність студентів до логічного мислення при вирішенні проблемних завдань, сприяє формуванню в них уміння аналізувати, синтезувати, абстрагувати, конкретизувати, узагальнювати набуті знання, спонукає їх до самостійного вивчення наукової та методичної літератури, розвиває професійну ініціативність, самостійність і відповідальність [4, с. 121-125].

Зупинимося на важливості моменту інтеграційних технологій на прикладі дисциплін, які вивчаються студентами-бакалаврами на завершальному етапі навчання в РМА. Так, в останньому семестрі студенти вивчають чимало дисциплін узагальнюючого характеру, коли надзвичайно важливо не засвоїти нові знання, 
а узагальнити вже набуті, використавши їх на практиці. Пропонуємо як приклад застосування міждисциплінарної інтеграції при вивченні дисципліни «Клінічна фармаколо- гія з основами фармацевтичної опіки» для студентів-фармацевтів першого (бакалаврського) рівня вищої освіти. Результати впровадження наводимо в таблиці 1 .

Таблиия 1

Міждисциплінарна інтеграція при вивченні дисципліни «Клінічна фармакологія з основами фармацевтичної опіки»

\begin{tabular}{|c|c|c|}
\hline Дисципліна & Знати & Уміти \\
\hline \multicolumn{3}{|l|}{ 1. Забезпечуючі: } \\
\hline Хімія & хімічну структуру засобів & класифікувати засоби за хімічною структурою \\
\hline Математика & основи математичних розрахунків & здійснити розрахунок дози ЛЗ \\
\hline Фармакологія & \begin{tabular}{|l|} 
призначення Л3, їх фармакокінетичні та \\
фармакодинамічні властивості
\end{tabular} & $\begin{array}{l}\text { раціонально здійснювати підбір Л3 відповідно } \\
\text { до клінічної ситуації }\end{array}$ \\
\hline $\begin{array}{c}\text { Основи } \\
\text { фармацевтичної } \\
\text { опіки }\end{array}$ & \begin{tabular}{|l|} 
алгоритм надання фармацевтичної опіки \\
в різних клінічних ситуаціях
\end{tabular} & $\begin{array}{l}\text { аналізувати алгоритми фармацевтичної опіки, } \\
\text { моделювати діалог із пацієнтом }\end{array}$ \\
\hline $\begin{array}{l}\text { Нормальна } \\
\text { анатомія та } \\
\text { фізіологія }\end{array}$ & $\begin{array}{l}\text { будову органів і систем організму та } \\
\text { принципи його функціонування }\end{array}$ & $\begin{array}{l}\text { здійснювати диференціальну характеристику } \\
\text { процесів у здоровому організмі }\end{array}$ \\
\hline $\begin{array}{c}\text { Патологічна } \\
\text { анатомія та } \\
\text { фізіологія }\end{array}$ & $\begin{array}{l}\text { ознаки патологічних процесів в організ- } \\
\text { мі людини }\end{array}$ & $\begin{array}{l}\text { диференціювати основні патологічні процеси } \\
\text { в організмі пацієнта }\end{array}$ \\
\hline Фармакогнозія & $\begin{array}{l}\text { застосування та зберігання ЛРС } \\
\text { у медицині }\end{array}$ & до застосування ЛРС \\
\hline \multicolumn{3}{|l|}{ 2. Наступні: } \\
\hline Фармакотерапія & $\begin{array}{l}\text { володіти інформацією стосовно ЛЗ щодо } \\
\text { їх анатомічно-терапевтичного застосу- } \\
\text { вання та хімічної будови, володіти базо- } \\
\text { вими знаннями стосовно діагностики та } \\
\text { терапії захворювань }\end{array}$ & $\begin{array}{l}\text { призначати раціональну фармакотерапію сто- } \\
\text { совно клінічних станів, що лікують ОТС-пре- } \\
\text { паратами }\end{array}$ \\
\hline $\begin{array}{l}\text { Фармацевтична } \\
\text { опіка }\end{array}$ & \begin{tabular}{|l|} 
рекомендації щодо раціонального режи- \\
му лікування
\end{tabular} & \begin{tabular}{|l|} 
розробляти алгоритми фармацевтичного опіки \\
в конкретній клінічній ситуації
\end{tabular} \\
\hline \multicolumn{3}{|c|}{ 3. Внутрішньопредметна інтеграція: } \\
\hline $\begin{array}{c}\text { Загальна клінічна } \\
\text { фармакологія }\end{array}$ & \begin{tabular}{|l|} 
фармакокінетику, фармакодинаміку Л3, \\
загальні підходи до терапії, володіти ін- \\
формацісю щодо випробування нових Л3 \\
\end{tabular} & $\begin{array}{l}\text { аналізувати Л3 стосовно фармакокінетичних та } \\
\text { фармакодинамічних показників, диференцію- } \\
\text { вати вид і призначення терапії }\end{array}$ \\
\hline $\begin{array}{c}\text { Приватна клінічна } \\
\text { фармакологія }\end{array}$ & $\begin{array}{l}\text { застосування ЛЗ як у конкретних напря- } \\
\text { мах клінічної практики, так і на рівні } \\
\text { окремих нозологічних форм і клінічних } \\
\text { синдромів, особливості застосування Л3 } \\
\text { для надання раціональних рекомендацій } \\
\text { стосовно фармацевтичної опіки }\end{array}$ & $\begin{array}{l}\text { здійснювати вибір ефективних і безпечних ЛЗ } \\
\text { для лікування певного захворювання, визнача- } \\
\text { ти оптимальний шлях уведення Л3, лікарську } \\
\text { форму та режим застосування ЛЗ, надавати } \\
\text { рекомендації стосовно фармацевтичної опіки }\end{array}$ \\
\hline
\end{tabular}

Таким чином, для якісного і повномасштабного вивчення дисципліни «Клінічна фармакологія з основами фармацевтичної опіки» студентові необхідно володіти комплексними знаннями 3 хімії, математики, фармакології, основ фармацевтичної опіки, нормальної анатомії та фізіології, патологічної анатомії та фізіології, фармакогнозії. Набуті в процесі вивчення знання майбутні фахівці зможуть застосувати під час проходження фармакотерапевтичної практики та здійснення фармацевтичної опіки клієнтам аптек.

Також нами був опрацьований міждисциплінарний процес стосовно дисципліни «Медичне та фармацевтичне товарознавство» для майбутніх медичних сестер. Результати роботи представлено в таблииі 2.

Як бачимо, для якісного і повномасштабного вивчення дисципліни «Медичне та фармацевтичне товарознавство» студентові необхідно володіти комплексними знаннями з технологічних дисциплін, хімії, біології, фізики, математики, маркетингу, організації та економіки фармації, мікробіології та фармакології. Набуті в процесі навчання у ЗВО знання майбутні фахівці зможуть застосувати в хірургії, терапії, лабораторній діагностиці, а також у ході аптечної практики. 
Міждисциплінарна інтеграція при вивченні дисципліни

Таблиияя 2 «Медичне та фармацевтичне товарознавство»

\begin{tabular}{|c|c|c|}
\hline Дисципліна & Знати & Уміти \\
\hline \multicolumn{3}{|l|}{ 1. Забезпечуючі: } \\
\hline Фізика, хімія, біологія & властивості матеріалів товарів & визначати показники даних властивостей \\
\hline $\begin{array}{l}\text { Технологічні } \\
\text { дисципліни }\end{array}$ & технологічні процеси & $\begin{array}{l}\text { 3’ясувати, як окремі технологічні процеси впли- } \\
\text { вають на якість товарів }\end{array}$ \\
\hline Математика & основи математичних розрахунків & здійснити кількісну оцінку якості товару \\
\hline Маркетинг & методи вивчення попиту на ринку & здійснювати планування товарообігу \\
\hline $\begin{array}{c}\text { Організація та } \\
\text { економіка фармації }\end{array}$ & $\begin{array}{l}\text { 3нання документації, що супроводжує } \\
\text { товар }\end{array}$ & заповнювати супровідні документи \\
\hline Мікробіологія & $\begin{array}{l}\text { характеристики патогенних мікро- } \\
\text { організмів }\end{array}$ & $\begin{array}{l}\text { досліджувати зміни, які відбуваються в това- } \\
\text { рах під впливом мікроорганізмів }\end{array}$ \\
\hline Фармакологія & \begin{tabular}{|l|} 
призначення Л3, їх фармакокінетич- \\
ні та фармакодинамічні властивості \\
\end{tabular} & раціонально здійснювати фармакотерапію \\
\hline \multicolumn{3}{|l|}{ 2. Наступні: } \\
\hline $\begin{array}{c}\text { Хірургія, терапія, } \\
\text { лабораторна діагнос- } \\
\text { тика, аптечна практика }\end{array}$ & $\begin{array}{l}\text { будову та характеристики товарів ме- } \\
\text { дичного та фармацевтичного призна- } \\
\text { чення }\end{array}$ & $\begin{array}{l}\text { здійснювати раціональне використання товарів у } \\
\text { доцільних ситуаціях }\end{array}$ \\
\hline \multicolumn{3}{|c|}{ 3. Внутрішньопредметна інтеграція: } \\
\hline $\begin{array}{c}\text { НТД на медичні та } \\
\text { фармацевтичні товари }\end{array}$ & \begin{tabular}{|l|} 
вимоги до товарів, їх класифікацію та \\
кодування. Управління якістю ЛЗ і ВМП
\end{tabular} & $\begin{array}{l}\text { диференціювати характеристики товарів із ме- } \\
\text { тою їх раціонального використання }\end{array}$ \\
\hline Матеріалознавство & властивості вихідних матеріалів & $\begin{array}{l}\text { уміти характеризувати товар, зважаючи на } \\
\text { матеріал, з якого він виготовлений }\end{array}$ \\
\hline $\begin{array}{l}\text { Товарознавство } \\
\text { медичне }\end{array}$ & \begin{tabular}{|l|} 
асортимент ВМП, хірургічних інстру- \\
ментів, терапевтичних приладів
\end{tabular} & $\begin{array}{l}\text { здійснювати підбір необхідного приладдя та } \\
\text { раціонально використовувати товарний асор- } \\
\text { тимент }\end{array}$ \\
\hline $\begin{array}{l}\text { Товарознавство } \\
\text { фармацевтичне }\end{array}$ & $\begin{array}{l}\text { асортимент ЛЗ, особливості їх фасу- } \\
\text { вання та зберігання }\end{array}$ & $\begin{array}{l}\text { раціональне зберігання та використання ЛЗ, то- } \\
\text { варів обмеженого аптечного асортименту, дезін- } \\
\text { фекційних, дезінсекційних засобів і репелентів }\end{array}$ \\
\hline
\end{tabular}

Висновки. Важливим i актуальним, особливо для студента-медика, $є$ сьогодні вивчення нової дисципліни в контексті інтеграційних технологій, що неодмінно спонукатиме студентів до своєчасного якісного процесу навчання, що $є$ не лише запорукою хорошої поточної успішності, а й комплексного підходу до освоєння кваліфікаційних знань.

3 огляду на вищевикладене, можемо зробити висновок, що необхідність використання інтеграційних технологій на кожному занятті спонукатиме студентів до кращого та глибокого оволодіння знаннями. Якщо такий підхід буде використаний педагогами компетентно, якісно та доброчесно, починаючи 3 першого курсу освітнього процесу, в студентів сформується чітке переконання необхідності системного підходу до навчального процесу 3 метою освоєння комплексних знань щодо обраної спеціальності.

Подальші дослідження в даному напрямі спрямовуватимемо на активне впровадження міждисциплінарної інтеграції в освітній процес підготовки студентів різних освітньо-кваліфікаційних рівнів медичних закладів вищої освіти.

\section{СПИСОК ВИКОРИСТАНОЇ ЛІТЕРАТУРИ}

1. Багрій М. М. Інтеграція навчального процесу у вищих медичних закладах / М. М. Багрій, Н. М. Воронич-Семченко, О. Г. Попадинець // Вісник проблем біології та медицини. - 2010. - Вип. 3. - С. 209-211.

2. Бех І. Д. Інтеграція як освітня перспектива / І. Д. Бех // Початкова школа. - 2002. - № 5. - С. 5-6.

3. Закон України «Про освіту» від 05.09.2017 №2145-VII.URL:https://zakon.rada.gov.ua/laws/show/214519 (дата звернення: 05.06.2019).

4. Кондрин О. С. Міждисциплінарний семінар i «кейс»-метод: взаємнодоповнюючі форми проблемного навчання / О. Є. Кондрин, М. М. Багрій, I. Ю. Ванджура // Галицький лікарський вісник. 2010. - T. 17. - № 2. - Ч. 1. - С. 121-125.

5. Посохова К. А. Результати впровадження нових технологій навчання при викладанні фармакології / К. А. Посохова, О. М. Олещук, О. О. Шевчук // Медична освіта. - 2012. - № 3 (додаток). - С. 133-135.

6. Чечотіна С. Ю. Актуальність упровадження міждисциплінарної інтеграції при вивченні фармакології / С. Ю. Чечотіна // Український стоматологічний альманах. - 2013. - № 4. - С. 86-89. URL: http://nbuv.gov.ua/UJRN/Usa_2013_4_25 (дата звернення: 05.06.2019). 